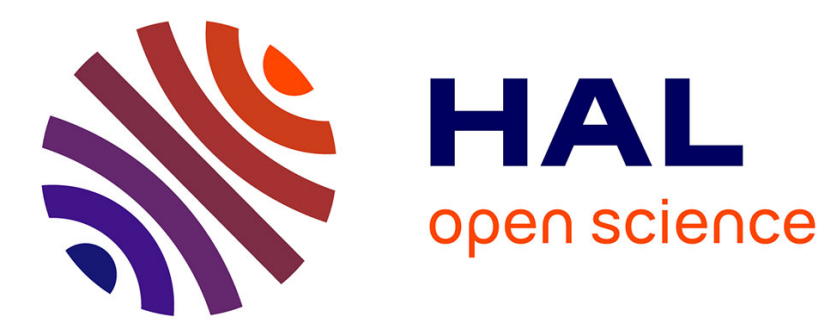

\title{
Public-private partnerships in hospital innovation: what lessons for hospital management?
}

Faïz Gallouj, Céline Merlin-Brogniart, Anne-Catherine Provost

\section{To cite this version:}

Faïz Gallouj, Céline Merlin-Brogniart, Anne-Catherine Provost. Public-private partnerships in hospital innovation: what lessons for hospital management?. Annual Meeting of the Academy of Management, Academy of Management, Jun 2011, San Antonio, United States. 10.4337/9781781002667.00019 . halshs-01113976

\section{HAL Id: halshs-01113976 \\ https://shs.hal.science/halshs-01113976}

Submitted on 6 Feb 2015

HAL is a multi-disciplinary open access archive for the deposit and dissemination of scientific research documents, whether they are published or not. The documents may come from teaching and research institutions in France or abroad, or from public or private research centers.
L'archive ouverte pluridisciplinaire HAL, est destinée au dépôt et à la diffusion de documents scientifiques de niveau recherche, publiés ou non, émanant des établissements d'enseignement et de recherche français ou étrangers, des laboratoires publics ou privés. 


\section{Public-Private Partnerships in Hospital Innovation: \\ What Lessons for Hospital Management? ${ }^{1}$}

\section{Authors:}

Faïz Gallouj, University of Lille 1, Clersé, Faiz.Gallouj@univ-lille1.fr

Céline Merlin-Brogniart, University of Lille 1, Clersé, c.brogniart-merlin@ieseg.fr Anne-Catherine Provost, Louvain School of Management, Mons Campus, annecatherine.provost@fucam.ac.be

\section{Abstract (100 words)}

Healthcare systems in developed countries are facing enormous socio-economic challenges. The development of cooperation between healthcare providers and of publicprivate partnerships (PPPs) has emerged as a priority area in the restructuring of the healthcare landscape everywhere. However, these PPPs are regarded essentially in economic terms, as means of cost reduction, which fails to do justice to the multiplicity of innovation dynamics at work. Drawing on an in-depth case study of a PPP and on theoretical models of service innovation, we investigate the complex and many-sided natures of hospital innovation associated with certain PPPs and formulate a number of managerial recommendations.

\footnotetext{
${ }^{1}$ This research is part of the ServPPIN European Research Project (The contribution of public and private services to European growth and welfare and the role of public and private innovation networks (FP7)).
} 


\section{Public-Private Partnerships in Hospital Innovation: What Lessons for Hospital Management?}

Healthcare systems in all developed countries are facing changes in the demand for healthcare, caused by the conjunction of a multiplicity of demographic, medical and socioeconomic factors. Expenditure on healthcare has grown at a furious pace and governments are now having to find ways of curbing that growth. According to OECD Health Data (OECD, 2010), France had the second-highest level of health expenditure relative to GDP of all OECD countries in 2008, with only the USA outstripping it. Almost $80 \%$ of this expenditure is funded from the public purse.

Faced with these challenges, the French government embarked in the 1990s on a major reform of the hospital sector. In 1996, a regional administrative apparatus for the hospital system was put in place with the establishment of the Regional Hospital Services Agencies (Agences Régionales d'Hospitalisation/ARH) and a new obligation on all hospitals to seek accreditation. In 2003, an ambitious reform plan, known as Plan Hôpital 2007, was launched. It had three objectives: 1) to modernise hospitals and improve their general infrastructure, much of which was run-down and dilapidated; 2) to establish closer links between funding and activity and 3) to improve hospitals' internal functioning by encouraging better dialogue between clinicians and hospital management (Molinié, 2005).

The development of cooperation between public and private healthcare providers and of public-private partnerships is one of the priority areas in the restructuring of the healthcare landscape. In 2004, Healthcare Cooperation Groups ${ }^{2}$ (HCG) were set up to provide the legal

\footnotetext{
${ }^{2}$ Groupement de coopération sanitaire (GCS)
} 
framework for cooperation between public and private hospitals ${ }^{3}$. The ARHs were replaced in April 2010 by the Regional Health Agencies (Agences Régionales de Santé/ARS). These new bodies have a wider remit that encompasses both restructurings and improvements in hospital efficiency.

It has to be acknowledged that these public-private partnerships are seen primarily in economic terms, as means of reducing costs. This perception of PPPs is based on two more or less explicit premises. The first, explicit premise is that savings can be made by reducing duplication, seeking complementarities and pooling expensive resources. The second, more implicit premise is based on the notion that the private sector is more efficient than the public sector and that, consequently, cooperation between the public and private sectors, regardless of the form it may take, will lead to improvements in the overall efficiency of the system. This second premise is consistent with the more general strategy of introducing private-sector management techniques into the public sector (new public management).

Considered in this way, these PPPs are, in reality, a black box when it comes to innovation (Rosenberg, 1982), both for their promoters and for the public authorities. After all, the underlying hypothesis, in essence, is that bringing together public and private resources, whether they be material, financial or human, is likely to increase the efficiency of the healthcare system, through the workings of mechanisms which, when all is said and done, are themselves of little consequence.

The aim of this article is to show that the implementation of PPPs sets in train a complex innovation dynamic. This dynamic may affect many different facets of a hospital's output, whether viewed quantitatively (efficiency of the care provided) or qualitatively

\footnotetext{
${ }^{3}$ Although the GCSs were set up in 1996 (decree of 24/04/1996), their remit was defined only in the decree of 4/09/2003, which came into force in 2004.
} 
(effectiveness of the service provided, above and beyond the actual medical treatment). It can be considered at different analytical levels (that of the organisation itself, as well as the intra and inter-organisational levels). An innovation dynamic of this kind is particularly manysided. Its boundaries seldom coincide neatly with any single form of innovation among those proposed by economic theory ${ }^{4}$. PPPs may provide the impetus for a complex, many-sided package of innovations and a range of learning processes, the content and mechanisms of which need to be understood.

The complexity of such a package can be explained in various ways. One explanation is the multiplicity of different forms of innovation produced (product, process, market, organisational, strategic, social etc.) and the wide variation in intensity (radical, incremental, ad hoc). Another explanation is the diversity of sources of innovation associated with PPPs. The innovations may, after all, be adopted, produced or co-produced. They may be the result of bottom-up or top-down processes; they may be intentional and programmed or, on the contrary, they may emerge unexpectedly (ad hoc) from an interactive process and be validated, if at all, only in retrospect. The final explanatory factor is the diversity of occupations and actors involved in the innovations, as well as their very diverse objectives and modes of justification. Those involved may, of course, include all the healthcare professions and not just doctors and the higher intellectual healthcare professions, as well as any other profession or occupation within a hospital, such as employees in hotel/housekeeping services, catering, transport, administration, etc.

Our purpose in this article is to abandon the default 'standard' approach to innovation in order to effect entry into the 'black box' of hospital innovation. In order to breach this

\footnotetext{
4 Thus in the cases we are considering, the traditional official questionnaires (INSEE survey, community innovation surveys) prove to be rather inappropriate.
} 
black box, we draw on the framework for analysing hospital output and innovation developed by Djellal et al. (2004) (see also Djellal \& Gallouj, 2005, 2008a), which we will apply to an in-depth case study of an innovation-oriented PPP (IPPP). We hope in this way to account theoretically and empirically for the complex, multifaceted nature of innovation in hospitals and to draw some general lessons for hospital management involved in IPPPs.

The article is divided into four sections. In the first section, we present a theoretical framework for analysing hospital output, which we consider capable of accounting for the full complexity of innovation in this sector. In the second section, we discuss the notions of PPP and innovation-oriented PPP in hospitals, in order to demonstrate that their contents are multifaceted and diverse. We also identify the form of PPP that interests us here, namely PPPs that generate a complex, architectural innovation dynamic as defined by Henderson and Clark (1990). In the third section, using the example of an in-depth case study of an IPPP involving a public and private hospital and drawing on the analytical framework developed in the first section, we seek to explain the multidimensional nature of innovation in hospitals. The final section is given over to the implications of our theoretical framework and case study for hospital management.

\section{THE HOSPITAL AS A COMPLEX SERVICE SYSTEM AND ITS INNOVATION DYNAMIC}

Traditional economic analysis regards hospital activity as a production function like any other (for a survey see Djellal \& Gallouj, 2007). Consequently, the introduction of innovation is considered essentially from the point of view of reducing production costs. From this perspective, PPPs are an attempt, similarly, to increase organisational efficiency by reducing production costs. Thus innovation is regarded exogenously, with the main consideration being the outcome of an invisible process as measured in terms of economic efficiency (see Figure 1). 
Insert Figure 1 about here

This approach to the product, to innovation and indeed to partnership does not seem to us sufficient to account for the complexity of the phenomena at work in an IPPP. Consequently, we put forward a different representation of a hospital's product that will enable us to enter the black box in order to better understand the full complexity of innovation and to identify some levers for practitioners and the public authorities to activate.

\section{The hospital as a complex package}

Hospitals can be considered as packages of goods, services, competences and tangible and intangible technologies that are combined in order to (co)-produce with clients utilities or service characteristics (Djellal \& Gallouj, 2004, 2005, 2008a). This approach to hospital output has its roots in two complementary fields of research.

The first field focuses on the definition of services. It consists essentially of the studies by Gadrey (1996a, 2000) and Hill $(1977,1999)$, who define a service as a process leading to a change in the state of a given reality. In such a process the changed realities belong to a finite set. We may, after all, be dealing with a tangible object, codified information, an individual or the cognitive components of an organisation. A definition of this kind grants a central position to interaction with the customer (co-production); at the same time, it also makes it possible to break a service down into its various functions or operations (Gadrey, 1991, Gallouj, 1999): - logistical and material processing operations (M), involving the movement, transport, transformation and any other form of processing of tangible objects;

- logistical operations and those involving the processing of codified information (I) (production, transformation, transfer, archiving, etc.); 
- knowledge processing operations (K) using intangible technologies, and codified methods and routines;

- and finally, contactual or relational service operations $(\mathrm{R})$, which consist of a direct service provided in contact with the customers and with a variable degree of interaction.

The second field of enquiry is based on an approach to product and innovation in terms of characteristics. This is a theoretical perspective that has its roots in Lancaster's approach to consumer theory and in which the product is defined as the conjunction of vectors of characteristics and competences. Initially developed by Saviotti and Metcalfe (1984) in order to describe technical systems and their evolution (a car, for example), this approach was extended to services by Gallouj and Weinstein (1997) (see also Gallouj, 2002). Gallouj and Weinstein (1997) define the product, whether it is a good or a service, as the combination or conjunction of vectors of characteristics and competences: service characteristics [Y], internal technical characteristics $[\mathrm{T}]$, external technical characteristics $\left[\mathrm{T}^{\prime}\right]^{5}$, internal competences $[\mathrm{C}]$ and external competences [C'] (see Figure 2).

Insert Figure 2 about here

The representation in Figure 2 can be used very flexibly. It can represent a material artefact or an immaterial or intangible product. It can represent a pure service, a less pure service or even a self-service situation $\left(\left[\mathrm{C}^{\prime}\right]-[\mathrm{T}]-[\mathrm{Y}]\right)$. It can also be used to illustrate the provision of hybrid solutions.

\footnotetext{
${ }^{5}$ Inclusion of the customer's technical characteristics was suggested by De Vries (2006), in order to take into account the new channels of consumption and delivery (e.g., when consumers use their own technologies in order to access services on the web).
} 
This characteristics-based approach is faithful to the theoretical definition of services (see above), particularly since the client (the consumer or patient), as represented by his or her competences, is an endogenous component and the technical characteristics [T] can be linked to the various operations (material, informational, cognitive and relational) that make up the product.

This general representation of the product (good or service) can be improved by introducing the competences and technologies of the other providers when the service is delivered through a network (De Vries, 2006). It may also be useful to introduce the public authorities, particularly in order to represent innovation in public services (Windrum \& Garcia-Goni, 2008).

However interesting they may be, the two fields (sources of inspiration) outlined above are still relatively theoretical. The idea put forward by Djellal and Gallouj (2005) is to use them as a basis for developing a more operational analytical framework. Thus they propose an analytical model that represents the hospital product as a composite of the various components listed below (see Table 1):

1) A combination of constituent services $\left(S_{i}\right)$ belonging to different groups: health services of various kinds, obviously, as well as peripheral services that are essential to the provision of treatment (e.g., administrative services, hotel/housekeeping, catering, transport, cleaning services). These are represented by the rows in the analytical table.

2) A functional decomposition of the constituent services. This decomposition is based on the hypothesis (alluded to above) that all service activities can be broken down (in differing proportions that also vary in space and over time) into processing operations or functions applied to material objects, information, knowledge or individuals. These various 'material' 
(M), 'informational' (I), 'methodological' (K) and 'relational' (R) operations are associated with particular technologies. This functional decomposition, which is also therefore a technological decomposition, is represented by the columns in the analytical table.

3) The competences (C) mobilised by the service provider. This may be an individual or a restricted group (the team or teams involved in providing the service). These competences are located 'upstream' of the functional decomposition. They may be competences associated with the technologies and various types of operations carried out or they may be competences mobilised directly (without any technological mediation) in order to produce utilities (Y). In the second case, we are dealing with a 'pure' service situation.

4) The service or use characteristics (Y) of the service provided, considered from the client's point of view. These characteristics describe the utilities (in the meaning given to the term in economic theory) derived from the mobilisation (in the course of the various types of operations that constitute the service provided) of the internal technical components and/or competences. They are located 'downstream' of the product decomposition.

Thus Table 1 provides a relatively simple representation of the hospital product, in all its functional and technological diversity. Thus a hospital's service provision can be represented simply as the aggregation of various kinds of constituent services $\left(\mathrm{S}_{\mathrm{i}}\right)$. Each of these $S_{\mathrm{i}}$ can itself be envisaged as the combination, to varying degrees, of constituent operations carried out on objects, information, knowledge or individuals. In other words, the columns in Table 1, the variables $\mathrm{C}, \mathrm{Y}$ and the group (M, I, K and R) are not located at the same level of analysis. After all, M, I, K and R are 'internal' functions or components of the product, while $\mathrm{C}$ is located upstream and $\mathrm{Y}$ downstream of the service (they are external functions). This means that the competences contribute to the implementation of the 
corresponding operations and technologies, which find expression in the provision of the service characteristics.

Insert Table 1 about here

This framework for analysing the hospital product is attractive for a number of different reasons. 1) It is a simple heuristic that is based on well-established theoretical foundations (service economy, Lancasterian approach). 2) It does not reduce hospitals, as is often the case, to a single function (provision of medical treatment) but extends the range of spheres and actors involved in innovation to many other functions (catering, hotel/housekeeping services etc.). 3) Hospitals and their various constituent elements are considered in terms of the different types of functions and technologies they deploy, which extends the range of innovation forms and trajectories. 4) This framework also constitutes a flexible tool that can be used to investigate the hospital product at various levels: at the intraorganisational level, i.e. that of the constituent services $\left(\mathrm{S}_{\mathrm{i}}\right)$, which can themselves be subdivided into constituent sub-services $\left(\mathrm{s}_{\mathrm{i}}\right.$; ; the organisational level (a hospital, for example); at the inter-organisational level (the networks established between different healthcare establishments and actors).

\section{The organising principles driving innovation in hospitals}

The literature on hospitals favours a technological and medical conception of innovation. The representation of the product set out above (Table 1) can be used to go beyond these technological and medical approaches in order to reveal the full diversity of forms of innovation and innovation trajectories to be found in hospitals. Innovation can, after all, be defined as an action affecting the squares, rows and columns in the table. These actions can, in theory, give rise to a considerable number of different configurations. According to 
Djellal et al. (2004), however, they can be reduced to a relatively small number of basic organising principles or logics, which can be described as extensive, regressive, intensive and combinatory.

The extensive organising principle will lead to rows being added to the table; these rows represent additional constituent services, whether they be medical services or any other type of constituent service. The regressive principle describes the opposite case. Here, certain constituent services are eliminated; this is depicted by a loss of rows from the analytical table. The intensive organising principle, for its part, involves the enhancement, in various ways, of the columns of our analytical framework. Depending on the medium concerned, this organising principle enables us to identify a number of different trajectories: a logistical and material transformation trajectory, a logistical and information processing trajectory, a methodological and cognitive trajectory, a pure 'service' trajectory and, finally, a relational trajectory. The combinatory principle, finally, is commonly encountered and is based on the various principles described above. It manifests itself in the repeated and linked implementation of various 'pure' organising principles (see Table 1):

- the addition and/or elimination (association or dissociation) of constituent services (action affecting the rows on the analytical table),

- technological intensification and/or its opposite (action affecting the columns of the analytical table). In concrete terms, this organising principle manifests itself, in the same way as previously, in the addition and/or elimination (association and/or dissociation) of technologies or competences. These mechanisms may manifest themselves within a given technological sphere or affect several spheres (columns).

\section{FROM PRODUCTION-ORIENTED TO INNOVATION-ORIENTED PPPS IN HOSPITALS}

The various notions of what constitutes a PPP in a hospital (as elsewhere) can give rise to considerable confusion, since the boundaries are not clearly defined and vary from one 
author to another. They are often used to describe very diverse forms of relationships between the public and private sector (Linder, 1999, Widdus et al., 2001, Reich, 2002, Bradford, 2003, Wettenhall, 2003, Saves \& Scheid, 2008, Mazouz, 2009). PPPs differ in various ways: in the number of partners involved, in the nature, intensity and duration of the relationship that is established, in the purpose of that relationship, etc. A distinction can be made between production-oriented PPPs, the oldest and most familiar form, and innovation-oriented PPPs. It is these latter, which are more recent and less familiar, that concern us here and on which we will concentrate, having first briefly described production-oriented PPPs.

\section{Production-oriented PPPs (PPPPs)}

In what we have suggested calling production-oriented PPPs, the term 'production' may refer to a number of different things (e.g., the realisation of an infrastructure project or the provision of a service, which may take various forms, such as a concession or a joint venture). In the case of a joint venture, the 'production' includes not just the production of the service (servuction) but also all the activities that may be associated with it (management, maintenance, investment, etc.).

Although these two activities - infrastructure production (building) and service production (operating) - can be separated, they are frequently combined (bundling). In all cases, however, it can be said that, in essence, the activities that take place within the scope of production-oriented PPPs are known and can be the object of contracts. Whatever their form and purpose, from the public partner's perspective, the justification for this type of PPP is that they are a means of either reducing costs and increasing efficiency or making up for a lack of expertise or financial resources.

\section{Innovation-oriented PPPs (IPPPs)}

In contrast to production-oriented PPPs, the principal and explicit purpose of innovation-oriented PPPs is to implement innovation. Just like production, however, 
innovation has to be considered in its various senses. Innovation-oriented PPPs are not themselves homogeneous, since they vary in both scope and content. Four types of innovation-oriented PPPs (IPPPs) can be identified, arranged in ascending order of complexity: 1) simple IPPPs with a focus on technology adoption; 2) simple IPPPs with a focus on the production of technological innovation; 3) simple IPPPs with a focus on the production of non-technological innovation; 4) complex or architectural IPPPs. The difference between a simple and a complex IPPP is the number of objects of innovation. Moving from the former to the latter involves a shift from a simple, explicit contract to combination of implicit and explicit contracts. Even though their main purpose is innovation, IPPPs also of course involve production.

\section{Simple IPPPs}

Simple IPPPs have clearly identifiable objects of innovation, in many cases just a single one, and are reducible to a contract. Varying degrees of simplicity can however be observed, with the actual level reflecting the source of the innovation and its nature. Thus IPPPs whose purpose is the adoption of an innovative technology are simpler than those whose aim is to produce such an innovation. And within this second group, those IPPPs set up with a view to producing a technological innovation are simpler than those whose purpose is to produce a non-technological innovation.

- Simple IPPPs set up for the purpose of technology adoption describe partnerships between a public and private hospital for the purpose of acquiring a complex, innovative technology, which requires significant investment, and to organise joint use of that technology. This is an IPPP in the sphere of innovation consumption. The institutions that regulate the hospital system have favoured this type of minimal collaboration between the public and private sectors. 
- Simple IPPPs whose aim is to produce technological innovations are set up when a hospital is participating in technological innovation projects. The purpose here is not technology adoption but rather the coproduction of innovation. In other words, a public hospital becomes part of an innovation network established for the purpose of producing technological innovations. The innovations in question are frequently medical innovations. The literature on these scientific and technical innovation networks involving both public and private-sector organisations in the medical sphere is very extensive. It constitutes a sub-group of an even more extensive group of studies on innovation networks and systems: technico-economic networks (Callon, 1991, Cohendet et al., 1998, Hakansson \& Snehota, 1997), national, local and sectoral innovation systems (Lundvall, 1992, Nelson, 1993, Edquist, 1997, Breschi \& Malerba, 2005), clusters (Porter, 1990), etc. These networks can also be extended by including innovations in hospital information systems (e.g., the Plan Hôpital 2012).

- Simple IPPPs with a focus on non-technological innovations are set up in order to develop non-technological (i.e., organisational, social or methodological) innovations. This group includes the many PPPs set up with the aim of establishing innovative treatment networks. These networks generally focus on patient support problems. The forms of coordination are often innovative such as the mode of funding which takes into account this coordination effort $^{6}$ (Riondet, 2009). Examples abound in this area, whether it be elderly care networks (Billard, 2001, Rapiau \& Riondet, 2004) or the HIV networks established in the early 1980s (Domin, 2002) that brought together doctors in private practice and their hospital colleagues. These health networks, which were made official in 1996, very often take the form of Healthcare Cooperation Groups (Groupements de Coopération Sanitaire/GCS) or non-profit

\footnotetext{
${ }^{6}$ Such as the fixed sum per patient per year.
} 
associations (Associations Loi 1901) (Plu et al., 2009). Other networks have also been established to deal with other medical or medico-social problems, such as diabetes, obesity, cancer, hepatitis $\mathrm{C}$, precarity and perinatality, or support the provision of palliative care for adults with neuromuscular diseases (Pellieux \& Fouquet, 2003) or with the prevention of suicide. The territory covered by these networks varies in size. They may be confined to the micro-local level or extend over a whole region or even a whole country ${ }^{7}$.

These IPPPs are the most complex of the simple IPPPs. This complexity arises out of the intangibility of the innovations produced, the important role played by knowledge and tacit technologies and the large number and diversity of actors involved. The relationships established in this context are more difficult to regulate through an explicit contract.

\section{Complex IPPPs}

It is complex or architectural IPPPs that are our concern here. They are driven by the combinatory or architectural principle, since they combine all the mechanisms at work in the preceding cases. They are IPPPs that are set up in order to implement what might be called an organisational meta-change, in the sense that it combines most of the principles at work in simple IPPPs, whether the innovation in question involves the joint adoption of one or more technologies or the co-production of various forms of technological or non-technological innovations. Complex IPPPs owe their complexity to the multiple forms of innovation that they occasion. They pose many managerial problems due to the interactions between these different forms of innovation and to the fact that some of these forms are "non-programmed" and "emergent" ones.

${ }^{7}$ For example, the GCS 3C Rouen-Elbeuf is responsible for all oncology services in the Rouen-Elbeuf health district (about 800,000 inhabitants), or about half of all the regional oncology services (Delas, 2009). 
The various types of IPPP identified above fall within the scope of the 'assimilation, demarcation, integration' analytical framework suggested by Gallouj (1994) as a means of accounting for the various ways of envisaging innovation in services (for a recent survey of the literature on innovation in services see Gallouj and Djellal, 2010, Gallouj and Savona, 2009).

Thus IPPPs whose purpose is either the adoption or production of technological innovations fall within the scope of the assimilation perspective. From this perspective, innovation in services is synonymous with technological innovation (adopted or produced), as is very often the case in manufacturing industry. This autonomous production or coproduction of technological innovations is relatively common in health services. This sets them apart from most services, which tend to adopt rather than produce technical systems.

PPPs whose purpose is to produce non-technological innovations fall within the scope of the demarcation or differentiation perspective. They emphasise the distinctive aspects of innovation in services, the 'invisible' or 'hidden' forms of innovation (intangible product innovation, organisational, social and strategic innovation, etc.), those that elude the traditional tools used in the economics of innovation: they do not rely on R\&D expenditures and do not lead to patent applications.

IPPPs whose purpose is to produce complex architectural innovations fall within the scope of the integrative approach to innovation in services, that is an approach that takes into account the visible and invisible forms, the technological and non-technological forms of innovation (Gallouj \& Weinstein, 1997). The type of IPPP with which we are concerned in this article is the complex IPPP, since it makes use of the mechanisms underlying all the other types. The analytical framework described would appear capable of giving an account of such IPPPs. In the following section, it is put to the test in an actual case study. 


\section{AN EXAMPLE OF A COMPLEX, INNOVATION-ORIENTED PPP IN A HOSPITAL}

The public-private partnership examined here was established in 1999 between a public and a private hospital in Northern France. The original thinking behind the partnership was that costs could be reduced by eliminating duplication and establishing cooperation based on complementarity in a regional context in which hospitals were in competition with each other. However, the processes that were put in place triggered complex change and innovation dynamics. A number of key events that have marked the evolution of this PPP will be examined, with the focus of the analysis being gradually narrowed as we move from the interorganisational via the organisational to the intra-organisational level, in accordance with the three levels of analysis derived from our theoretical framework.

The first sub-section is given over to a brief outline of the case and the methodology. Adopting an inter-organisational perspective, we draw on our analytical framework in order to identify the duplications and possible complementarities and to account for the first cooperation agreements and the establishment of treatment networks (initial level of cooperation). The culmination of this PPP was undoubtedly the building of a hospital for joint use, which gave the partnership concrete form and, to some degree, locked the partners in and made it irreversible. The analytical focus of our model shifts here to the organisational level, since our aim is to account for the construction of a new organisation. Finally, we narrow the focus of our analysis even further to examine the intra-organisational consequences of the partnership.

\section{An exploratory case study}

Since our purpose is to effect entry into the 'black box' of the innovation brought about by PPPs, we have adopted a method based on an in-depth case study and qualitative analysis. The criteria guiding our choice of case were, firstly, the nature of the innovation and, secondly, the duration of the partnership. 
The chosen case is a PPP set up between a French public hospital (the Centre Hospitalier de Valenciennes) and a private, non-profit-making hospital (the Clinique Teissier) providing services for the public healthcare system. This cooperation between the two organisations could be simply described as an organisational innovation. However, this description fails to do justice to all the innovation, change and learning dynamics at work. After all, this meta-change is a process that has unfolded over time and encompasses a multitude of changes in products/services, processes, internal organisation and external relations. We are dealing, therefore, with a complex architectural innovation (see Figure 3).

A public-private partnership is a process that unfolds and bears fruit over time. It is formalised only gradually. Thus in the case under investigation here, the partners moved from simple agreements to the establishment, first, of an economic interest group ${ }^{8}$ and then of a healthcare cooperation group (HCG), reflecting a gradual increase in the partnership's degree of formalisation as the cooperation between the two hospitals evolved and became more complex. Thus at the time our investigations were carried out, the PPP had been in place for 10 years, a sufficiently long period for us to be able to investigate the organisational innovation dynamic.

The Centre Hospitalier de Valenciennes (CHV) is a public hospital which, prior to the establishment of the PPP, had 1916 beds and employed 3500 people, including more than 300 doctors. The CHV is the second provider of hospital services in the Nord-Pas de Calais region, after the Centre Hospitalier Régional Universitaire in Lille (Lille Regional University Hospital), and among the 30 largest hospitals in France. The Clinique Teissier, for its part, belongs to the AHNAC (Association Hospitalière Nord-Artois-Cliniques) group. Its status is that of a private, non-profit-making hospital 'contributing to the public hospital service',

\footnotetext{
${ }^{8}$ Groupement d'intérêt économique (GIE)
} 
known in France by the abbreviation $\mathrm{PSPH}^{9}$. The Clinique Teissier has 170 beds and 300 employees, including 25 doctors ${ }^{10}$.

The data were gathered largely through semi-structured interviews, which were recorded and then transcribed. The interviews were structured around the following eight themes: the progression of the partnership (origins, evolution), the determinants/obstacles/facilitating factors, the keys to a successful PPP, the key actors and the role of leadership, the impact of the hospital reforms, the nature of the innovation, the contractual arrangements and the new internal organisation.

\section{The inter-organisational perspective: identifying the duplication and the first steps}

\section{towards partnership}

Before the partnership (in 1998), the Clinique Teissier had three departments: respiratory medicine, vascular and abdominal surgery and accident and emergency. The Centre Hospitalier de Valenciennes, which is located in the same road, had all specialities with the exception of heart surgery and major burns.

As Table 2 shows, there was a certain amount of duplication between the two organisations, whether in the constituent services provided or in the technical systems deployed. From a more qualitative perspective, moreover, the two hospitals were dilapidated and their technical infrastructures obsolete. Consequently, the Regional Hospital Services Agency, the body responsible for implementing regional policy on the supply of hospital services, made the funding of any investment conditional on the development of a partnership

\footnotetext{
${ }^{9}$ This type of hospital is midway between the public hospitals and the private, for-profit hospitals. They are funded in the same ways as the public hospitals and have a public service mission. However, their doctors are salaried staff not civil servants, as they are in the public hospitals.

${ }^{10}$ Comparison of the numbers employed would suggest that the balance of power strongly favours the public hospital. In reality, the two are more evenly balanced than they seem to be at first sight because the private hospital belongs to a larger group, the AHNAC, which is made up of 12 institutions with a total of 1738 beds and 3200 employees, 231 of them doctors.
} 
between the two hospitals. In 1999, the hospitals signed a partnership agreement with the following aims: to eliminate duplication, to modernise the two hospitals, and to achieve a critical size in order to be able to meet increased competition from the private, for-profit sector.

Insert Table 2 about here

One of the first manifestations of this partnership was the establishment of treatment networks in which, besides the two hospitals, doctors in private practice are also involved (i.e., inter-organisational combinatory innovation, Djellal et al., 2004). In our case, the most significant network is the one established between the $\mathrm{CHV}$, the Clinique Teissier and doctors in private practice to provide respiratory medicine services. This network gives the doctors in private practice access to the hospitals' technical facilities and equipment and even to the private hospital's beds.

In order to prepare for the next phase of the partnership (the construction of a new high-tech building), each partner embarked upon several preliminary projects (Devillers, 2005). Thus in 2003, the CHV opened a new long-term care centre and in 2005 inaugurated a new mother and child centre. In the same year, it brought together all its laboratories in the same specialised building. It also completely restructured its logistical services (new central laundry, logistics centre, new central kitchen and above-ground car park). The CHV entered into a very large number of agreements with the Clinique Teissier. They constitute the partnership's second initial manifestation or initial operating mode.

\section{The organisational perspective: building a new hospital}

The second key stage in the evolution of the partnership is, in contrast, particularly tangible, since it took the very material form of the building of a new joint hospital and new 
technical facilities shared by the two institutions. The project in question was launched three years after the partnership agreement was signed, in 2002. The investment, a total of 190 million Euros, was funded under the terms of the 'Plan Hôpital 2007' launched by the French government in 2002 with the aim of modernising the provision of healthcare.

This project was to take 10 years to complete and resulted in the construction of a joint High Technology Medicine (HTM) building named the Jean Bernard Hospital ${ }^{11}$. It is the concrete manifestation of an organisational innovation without precedent in the French hospital system. The implementation of this PPP went beyond a mere agreement to collaborate on specific activities or on an architectural project. The aim was to create leadingedge medical centres based on a joint strategic plan in which activities were to be shared between the two institutions on a non-competitive basis. The new hospital has 735 beds and consists of an operating theatre block with 15 operating rooms, a neurosurgery block and an imaging centre with 5 interventional imaging rooms, 3 MRI machines, 3 scanners and a PET scanner.

It is the organisational perspective of the analytical framework we have adopted that is best suited to analysing this second phase of the partnership, since it provides us with a means of focusing on the new internal structure and the organisation of the many services and actors within it. This new organisational structure is depicted in Table 3, which shows how the activities were shared out between the two institutions (O1 and $\mathrm{O} 2)$ and the duplications eliminated (e.g., S1, T1, S8, S9, S10 or S11). Not only are the various constituent services now provided by only one of the two organisations but several departments and technical

11 This new building was constructed on the CHV site. The Clinique Teissier's main activities, with the exception of its administrative offices, were transferred there. 
support services are shared between the two. This applies to accident and emergency, pharmacy services, technical facilities and non-medical services, such as hotel and catering.

This new organisational structure reflects the combinatory innovation principle, as defined by Djellal et al. (2004). This principle manifests itself in the repeated and interlinked use of the various basic principles (intensive, extensive and regressive). It combines the mechanisms of regressive innovation with the elimination of several constituent services $(\mathrm{Si})$. Thus the Clinique Teissier closed down its department of vascular and abdominal surgery, while the CHV no longer has a department of respiratory medicine. Other departments are shared, as was noted above.

It also includes some of the mechanisms of extensive innovation, that is the addition of constituent services (Si). Since 2003, some 30 new activities have been developed (e.g., neurology, hospital at home services, or aftercare and rehabilitation).

This combinatory principle also draws, of course, on the intensive innovation principle, that is the strengthening of technologies (M, I, K) and competences (C), i.e. the columns in the table. The introduction of the shared technical facilities described above is a particularly spectacular example, as is the development of a joint information system (see below).

Insert Table 3 about here

This PPP goes well beyond collaboration between two partners on specific matters. It has in fact led to the total restructuring of service provision in the two hospitals (distribution of $\mathrm{Si}$ ) and to the establishment of a new system of hospital production (or servuction) with shared services (shared $\mathrm{Si}$ ). At the same time, however, the two separate administrative entities have been maintained and they retain their separate legal identities (O1 and $\mathrm{O} 2)$. As a 
result of this reorganisation, patients now follow a 'patient pathway' that is contained within a single building shared by the two hospitals.

This integration of the treatment process also highlights the need for a shared computerised information system in order to facilitate exchanges. The development of this system constitutes the final phase of this partnership. Thus a single computerised public/private patient file is in the process of development. This project, known as CADUCEE, is intended to produce a system that will be used to manage patient pathways and to ensure that patient care is optimised across all the departments involved, from the time a patient is admitted until he or she is discharged, with the referring doctor also being integrated into the system. It will give healthcare professionals secure access in real time to a patient's entire medical records, thereby simplifying patient transfer procedures.

\section{The intra-organisational perspective: a diversity of forms of innovation at the level of service provision}

The intra-organisational perspective provides us with a means of analysing the dynamic of change within a constituent unit (sij) of the new organisation, i.e. a department in the hospital or a constituent service $(\mathrm{Si})$, whether medical or non-medical.

The various constituent services accommodated in the new hospital have themselves been modified in various ways by force of circumstance, more specifically as a result of the reconfiguration of the work force (C) and the new architectural and technical environment (M, I, K, R). This observation applies to all the constituent services in the new organisational structure (medicine, hotel, maintenance, cleaning, transport, management, catering, laundry, etc.). These changes to the constituent elements of the functional breakdown lead to changes in the service characteristics (Y) (Extensive innovation logic such as the addition of a number of new surgical sub-specialities; intensive innovation logic such as reconfiguration of both the layout of the equipment and the system of work organisation). 
- The accident and emergency department provides another example of the multiple and complex changes that affect a constituent service and are an expression of the various innovation principles. Firstly, it has increased considerably in size (more than $3000 \mathrm{~m}^{2}$ now). If space is regarded as an intangible technical variable, this means that there has been a significant improvement in this variable (action on the corresponding column of the analytical table).

- The sharing of certain constituent services within the framework of the PPP has also made it necessary to completely redesign the hospital's logistics. For example, the use of a single catering department has changed practices in the Clinique Teissier (use of polypropylene containers instead of plates), since there is no dishwashing function in the new building.

Some of these organisational changes took place unintentionally, in the course of the process of reorganisation. However, most of the changes in the constituent services did arise out of well thought-out processes involving the various actors and coordinated by the Healthcare Cooperation Group (HCG). The entire staff of both hospitals met on a 'functional department' basis and discussed the necessary arrangements (procedures, personnel, etc.) for each service provided, as well as the administrative implications (in terms of payment, logistics, etc.). These divisions and procedures were then formalised and codified in agreements concluded under the umbrella of the HCG.

\section{WHAT LESSONS FOR HOSPITAL MANAGEMENT?}

As has already been noted on several occasions, the notion of the PPP is a flexible and adaptable one that can reflect organisational dynamics of varying scope. In the present article, we have focused on a PPP involving complex, architectural innovation that is reflected in 
multiple and complex changes in the products, processes and organisation of the hospitals concerned. The case investigated here and the analytical framework we have drawn on raise a number of interesting questions from the point of view of management (and public policies), the operational answers to which may be generalisable beyond the specific case under investigation here.

\section{Reconciling conflicting cultures: the public and private sectors}

The first significant challenge faced by advocates of closer cooperation between public-sector and private-sector organisations is the clash of what we shall call 'cultures', a term used, probably inaccurately, to denote a complex set of institutional and organisational arrangements and conceptions of products, services, missions and performance (including the definition and evaluation thereof). This clash of 'cultures' is a well-known obstacle to closer cooperation between the public and private sectors. It can manifest itself in two different ways: 1) deliberate resistance to change and closer cooperation and 2) unconscious (inertial) resistance linked to each organisation's intrinsic characteristics. These obstacles to partnership inevitably become obstacles to innovation when the purpose of the PPP is innovation.

Three theoretical scenarios can be envisaged for PPPs depending on which set of principles (public or private) prevails: in the first two, one or other set of principles predominates, while in the third there is a balanced mix (hybridisation) of the two. However, given the implicit objective alluded to above, the scenario in which public-sector principles are dominant can be excluded ${ }^{12}$. The second scenario, in which private-sector principles prevail, is conceivable in theory but unlikely in practice given the difficulty of reconciling the two cultures. Thus it is the hybridisation scenario that is the most probable and the most

\footnotetext{
${ }^{12}$ In our particular case, this statement has to be qualified somewhat, since both partners were providing public services.
} 
feasible. In this case, some of the principles of public service are retained but subjected to certain market constraints. This results in the partners negotiating a redefinition of their mission, which in the case investigated here led to the definition of a 'joint medical project'.

In the case of the PPP investigated here, the difference in culture between the two organisations did indeed constitute an obstacle to the development of the partnership ${ }^{13}$. The private hospital was organised on the basis of an 'artisanal' or 'craft' model that favoured 'familial' methods and management. In contrast, the public hospital operated along more industrial and bureaucratic lines (which made doctor/patient relations somewhat anonymous). Thus the doctors did not have their own patients; rather, they were treated, on a 'nonexclusive' basis, by a whole group of medical and non-medical staff. The private doctors' fear of losing their own patients proved to be a not insignificant obstacle during the negotiations and the implementation of the changes and innovations.

The different employment statuses of the two workforces (civil servants in the public hospital, salaried employees in the private hospital) also created a number of difficulties. Some individuals balked at changing organisations since that would entail a change of status. The question of governance in public hospitals seems to have been another obstacle to the development of this cooperative venture. The public hospital is, after all, a two-headed creature in which two competing decision-making systems confront each other: the medical staff, on the one hand, and the hospital management, on the other. This diffuse system of governance makes decision-making slow. Consequently, much time had to be spent in discussion and negotiation and some fifty joint agreements were drawn up on subjects as

\footnotetext{
${ }^{13}$ However, this difference in culture is smaller than it would be if we were dealing with a partnership with a profit-making private hospital. The Clinique Teissier is a private, non-profit-making hospital providing services for the public healthcare system.
} 
varied as the medical organisation of each department, meals, the morgue, waste management and even the laundry. It took ten years to put the partnership in place.

\section{Evolution over time and rationality}

Partnerships and innovation cannot be seen as discreet, instantaneous variables. Both involve sequential processes that unfold over time. The time frame lengthens as the IPPP in question increases in complexity. It is much longer for a PPP focusing on complex architectural innovation than for one whose main purpose is the adoption of an existing technology (see Figure 3).

The fact that an IPPP evolves over a long period of time means it comes up against the problem of the life cycle of individual careers. Although the actors in a PPP may remain stable in the short term, in the longer term certain key actors may leave the organisation, for various reasons. Thus in our case, the appointment of a new chief executive at the CHV made things difficult for the cooperative venture for some time, even though the new chief executive had been explicitly selected to continue developing the PPP and give it material form. The personalisation of strategies is undeniably a factor in the fragility of these cooperative processes (Devillers, 2005).

Although the partnership is necessarily intentional and based on an established strategy, this is not true of all the forms of innovation generated by the partnership dynamic. While certain innovations (particularly technical ones) are clearly programmed and listed in a project specifications document, many organisational innovations are not programmed. Also, the aim of an IPPP is not to achieve in the long run the best possible outcome in terms of the provision of hospital services but rather, at each stage of the process, to find a satisfactory solution resulting from a (temporary) compromise between the various principles governing product and performance. Thus pluralistic performance evaluation systems based on multiple 
and evolving criteria would be a means of more accurately capturing the socio-economic value of PPPs (Djellal \& Gallouj, 2008b, Merlin \& Moursli, 2010, Gadrey, 1996b).

\section{Innovation and its biases}

One significant problem for the management of PPPs in hospitals is the nature of the innovation and of the innovation processes. The problem can be discussed in terms of the following pairs of alternatives: 1) technological and non-technological innovation; 2) bottomup and top-down innovation; 3) medical and non-medical innovation.

\section{- Technological versus non-technological innovation}

The most visible form of innovation in hospitals (and the one that has been the subject of the most studies) is what is called medical innovation, which is in fact a generic label for various types of (mainly material or tangible) technological and bio-pharmacological innovations in patient treatment. Thus in this favoured approach, a hospital is understood as a 'set of technological and bio-pharmacological capacities' [4]. Another particularly visible form of innovation is that linked to NICTs. After all, hospitals are not immune to the allpervasive diffusion of NICTs resulting from the new informational paradigm. Thus a significant number of studies have adopted an approach in which hospitals are regarded as information systems and innovation in hospitals is considered in terms of its links with the informational paradigm. In some cases a (possibly artificial) distinction is made between information technology applied to administration (informational and material flows) and information technology applied to medical care itself.

This predominance of tangible technological innovation is frequently noted (and frequently deplored), not just in the literature on medical services (Djellal et al., 2004) but more generally in all studies on services (Gallouj \& Djellal, 2010, Howells, 2007, Tether, 2005, Miles, 2002, Coombs \& Miles, 2000, Sundbo, 1998, etc.). Thus this 'technologist bias' 
characterises what Gallouj (1994) calls the technologist or 'assimilative' approaches to innovation in services.

A differentiation or service-based approach (Gallouj, 1994) is required. This is the only approach capable of identifying and encouraging invisible or concealed forms of innovation in hospitals and medical treatment systems.

\section{- Medical and non-medical innovation}

Innovation in hospitals obviously involves both constituent medical services and the corresponding actors. However, it also involves all the other constituent services, such as hotel and catering, logistics, cleaning, etc. Here once again, as Djellal et al. (2004) note, analysts of innovation in hospitals tend to emphasise the first sphere of innovation to the detriment of all the others. In other words, the 'technological bias' referred to in the previous section is combined with a 'medical bias'.

In the search for efficiency, it is in the interests of hospital management and the public authorities to attach greater importance to non-medical forms of innovation. After all, the quality of non-frontline services obviously influences the quality and efficiency of frontline medical services themselves. This is particularly true of all cleaning services (cleaning, laundry etc.), which are essential in the fight against hospital-acquired diseases, but it also applies to all the 'commercial' services that affect the satisfaction (and loyalty) of patients as customers: quality of the hotel service, of the food, of reception and administrative services, of leisure services, etc.

\section{- Bottom-up and top-down innovation}

PPPs are initiated from on high, in accordance with the top-down principle: they are, after all, the result of strategic decisions taken at the top of hierarchical chains of command. 
Thus public-private cooperation contracts remain subject to the approval of the director general of the regional health agencies (Bergoignan-Esper, 2009). As was noted in subsection 4.2 above, a partnership's overall strategic orientations are set at the top of the hierarchy.

Nevertheless, it would be wrong to think that the innovations generated by PPPs also follow the top-down logic. As our case seems to demonstrate, the more complex a project is and the longer the period of time is over which it unfolds, the more local innovation dynamics and learning processes play an essential role. Viewed as a whole, the innovation process consists of contrary waves of bottom-up and top-down innovations that fit well with the processes and structures that have been thoroughly analysed in the literature on the economics and management of services (Toivonen, 2010): well-established project groups that follow sequential innovation models (stage-gate models), innovation processes based on bricolage (i.e., involving non programmed activities, trial and error processes and adaptation to random events) (Fuglsang, 2010), ad hoc or a posteriori recognition models in which the innovation is not programmed but emerges and is recognised retrospectively (Gallouj, 1991, Gadrey \& Gallouj, 1998) and rapid application models (Toivonen, 2010).

\section{CONCLUSION}

PPPs are forms of cooperation between the public and private sectors that have been undeniably successful in recent years. The main idea underpinning them is that private-sector organisations are able, by various means (by injecting funding, creating complementarities or simply by encouraging imitation), to improve the efficiency of public-sector organisations or of the new system the partnership constitutes in carrying out a given activity.

More recently, PPPs have also been regarded as mechanisms for producing innovations in services. As a result, PPPs have come up against a new difficulty, one that is not only theoretical but also of concern to managers and public policy makers, namely how to 
take account of what might be called invisible innovation. After all, if, as we suggest, the innovation associated with such partnerships is not regarded as a black box, then complex, multi-faceted forms of innovation are revealed that mobilise different actors at different organisational levels.

Drawing on theoretical models of innovation in services and applying them to an indepth case study, we have been able to analyse, at the inter-organisational, organisational and intra-organisational levels, the full complexity of the innovation dynamic associated with the implementation of a PPP in a hospital and to touch on the problems posed for management sciences.

Thus it seems that partnerships and innovation cannot be regarded as discreet variables: in order to be understood and managed appropriately, they must be situated within a time frame of greater or shorter length. As well as the need to adopt an evolutionary approach to performance evaluation, the cultural hybridisation that ensues from PPPs makes it necessary to use multi-criteria performance evaluations that take account of the market and socio-civic perspective.

Some forms of innovation are visible and predictable (programmed). This is true of most technological and architectural innovations. Many others, in contrast, are invisible (organisational innovations, social innovations, etc.). They tend to elude our theoretical tools and methods of measurement. They need to be recognised at both the theoretical and managerial levels.

Finally, while medical innovation and the actors involved in it play an essential role, hospital management (and public policies) should not neglect the innovations that occur in other (non-medical) spheres, since important forms of innovation can indeed emerge there. 


\section{REFERENCES}

Bergoignan-Esper, C. 2009. Les formes de coopération dans la loi HPST. Avancées et manques. Gestions Hospitalières, 489: 481-486.

Billard, V. 2001. Le réseau comme réponse à une meilleure prise en charge des personnes âgées. La communauté des établissements gériatriques de l'agglomération rouennaise. Gestions Hospitalières, 404: 165-169.

Bradford, N. 2003. Public-Private Partnership? Shifting Paradigms of Economic Governance in Ontario. Canadian Journal of Political Science, 36(5): 1005-1033.

Breschi, S. \& Malerba, F. (eds) 2005. Clusters, networks and innovation. Oxford University Press.

Callon, M. 1991. Réseaux technico-économiques et irréversibilité. In: R. Boyer et al. (eds.), Figures de l'irréversibilité en économie, 195-230. Paris: Edition de l'EHESS.

Cohendet, P., Lllerena, P., Stahn, H. \& Umbhauer, G. (eds) 1998. The economics of networks. Springer.

Coombs, R. \& Miles, I. 2000. Innovation, Measurement and Services: The New Problematique. In: J.S., Metcalfe \& I., Miles (eds), Innovation Systems in the Service Economy: Measurement and Case Study Analysis, 85-103. Dordrecht: Kluwer Academic Publisher.

Delas, A. \& Got, C. 2009. Organisation territoriale. Le GCS 3C Rouen-Elbeuf: une coopération originale en cancérologie. Gestions Hospitalières, 489: 487-490.

De Vries, E. 2006. Innovation in services in networks of organizations and in the distribution of services. Research Policy, 35(7): 1037-1051.

Devillers, M. 2005. La mise en place d'un groupement de coopération sanitaire : un simple changement de structure juridique? L'exemple du partenariat entre le centre hospitalier de Valenciennes et la clinique Teissier. Mémoire de l'Ecole Nationale de la Santé Publique.

Djellal, F. \& Gallouj, F. 2005. Mapping innovation dynamics in hospitals. Research Policy, 34: 817-835.

Djellal, F. \& Gallouj, F. 2007. Innovation in hospitals: a survey of the literature. The European Journal of Health Economics, 8(3): 181-193.

Djellal, F. \& Gallouj, F. 2008a. A model for analysing the innovation dynamic in services: the case of 'assembled' services. International Journal of Service Technology and Management, 9(3/4): 285-304.

Djellal, F. \& Gallouj, F. 2008b. Measuring and improving productivity in services: issues, strategies and challenges. Edward Elgar Publishers.

Djellal, F., Gallouj, C., Gallouj, F. \& Gallouj, K. 2004. L'hôpital innovateur. De l'innovation médicale à l'innovation de service. Paris: Masson.

Domin, J.P. 2002. Les réseaux ville-hôpital : vers un nouveau mode de régulation en santé publique? Gestions Hospitalières, 417, 449-456.

Edquist, C. (ed) 1997. Systems of Innovation: technologies, Institutions and Organizations. Pinter.

Fuglsang, L. 2010. Bricolage and invisible innovation in public service innovation. Journal of Innovation Economics, 5.

Gadrey, J. 1991. Le service n'est pas un produit: quelques implications pour l'analyse économique et pour la gestion. Politiques et Management Public, 9(1): 1-24.

Gadrey, J. 1996a. L'économie des services. Repères, La découverte.

Gadrey, J. 2000. The Characterization of Goods and Services: an Alternative Approach. The Review of Income and Wealth, 46(3): 369-387. 
Gadrey, J. \& Gallouj, F. 1998. The provider-customer interface in business and professional services. The Service Industries Journal, 18(2): 1-15.

Gadrey, J., Gallouj, F \& Ghillebaert, E, with the collaboration of Duplaa, D. \& Gallouj, C. 1996b. La Poste : Mondes de production, Types de produits, Contribution à la cohésion sociale. Rapport de recherche pour la Direction de la Stratégie de La Poste.

Gallouj, F. 1991. Les formes de l'innovation dans les services de conseil. Revue d'Economie Industrielle, 57: 25-45.

Gallouj, F. 1994. Economie de l'innovation dans les services. Paris: Editions L'Harmattan.

Gallouj, F. 1999. Les trajectoires de l'innovation dans les services : vers un enrichissement des taxonomies évolutionnistes. Economies et Sociétés, Série Economie et Gestion des Services, EGS 1: 143-169.

Gallouj, F. 2002. Innovation in the service economy: the new wealth of nations. Edward Elgar Publishing.

Gallouj, F. \& Djellal, F. (eds) 2010. The Handbook of Innovation and Services: a multidisciplinary perspective. Edward Elgar Publishers.

Gallouj, F. \& Savona, M. 2009. Innovation in services: a review of the debate and perspectives for a research agenda. The Journal of Evolutionary Economics, 19(2): 149172.

Gallouj, F. \& Weinstein, O. 1997. Innovation in Services. Research Policy, 26(4-5): 537-556.

Hakansson, H. \& Snehota, I. (eds.) 1997. Developing relationships in Business networks. Thomson Business Press.

Henderson, R.M. \& Clark, K.B. 1990. Architectural Innovation: The Reconfiguration of Existing Product Technologies and the Failure of Established Firms. Administrative Science Quarterly, 35: 9-30.

Hill, T.P. 1977. On goods and services. Review of Income and Wealth, 1: 315-338.

Hill, T.P. 1999. Tangibles, Intangibles and Services: a New Taxonomy for the Classification of Output. Canadian Journal of Economics, 32(2): 426-444.

Howells, J. 2007. Services and innovation: conceptual and theoretical perspectives. In: J. R., Bryson \& P.W., Daniels (eds). The Handbook of Service Industries, 34-44. Cheltenham: Edward Elgar.

Linder, S.H. 1999. Coming to Terms With the Public-Private Partnership. A Grammar of Multiple Meanings. American Behavioral Scientist, 43(1): 35-51.

Lundvall, B.-A. (ed) 1992. National systems of innovation. Pinter Publishers.

Mazouz, B. 2009. Les aspects pratiques de partenariats public-privé de la réthorique néolibérale... aux enjeux, défis et risques de gestion des PPP. Revue Française d'Administration Publique, 130: 215-232.

Merlin-Brogniart, C. \& Moursli-Provost, A.-C. 2010. Les dynamiques de l'innovation au sein des maisons de repos : le cas d'un établissement associatif. Economies et Sociétés, série Économie et Gestion des Services, 11: 197-230.

Miles, I. 2002. Service Innovation: Towards a Tertiarisation of Innovation Studies. In: J., Gadrey \& F. Gallouj (eds), Productivity, Innovation and Knowledge in Services, 164196. Cheltenham: Edward Elgar.

Molinié, E. 2005. L'hôpital public en France : bilan et perspectives. Bulletin Officiel Coll. Avis et rapports du Conseil économique et social.

Nelson, R. (ed) 1993. National innovation systems. Oxford University Press.

OECD Health Data 2010. Statistics and indicators. How does France Compare?

Pellieux, S. \& Fouquet, B. 2003. Un réseau régional de prise en charge des adultes atteints de maladies neuromusculaires. Gestions Hospitalières, 424: 211-214. 
Plu, I., Gignon, S., Emery, S., Purssell-François, I., Moutel, G. \& Hervé, C. 2009. Modalités et enjeux de la communication externe des réseaux de santé : l'expérience d'un réseau d'accès aux soins. Santé publique, 2(21): 173-181.

Porter, M. 1990. The competitive advantage of nations. Free Press.

Rapiau, M.-T. \& Riondet, J. 2004. La sortie d'hospitalisation des personnes âgées. Construire un axe stratégique entre l'hôpital et des associations d'aide à domicile. Gestions Hospitalières, 438: 536-540.

Reich, M. R. 2002. Introduction: Public-Private partnerships for Public health. In: M.R., Reich (ed.), Public-Private partnerships for Public health, 1-18. Harvard Center for population and development studies.

Riondet, J. 2009. Les réseaux de santé : enjeux de recomposition et de coordination des domaines d'intervention des professions. Science et société, 76: 98-115.

Rosenberg, N. 1982. Inside the black box: technology and Economics. Cambridge: Cambridge University Press.

Saves, F. \& Scheid, J.-C. 2008. Partenariat public-privé. Revue Française de Comptabilité, 416.

Saviotti, P.P \& Metcalfe, J.S 1984. A theoretical approach to the construction of technological output indicators. Research Policy, 13: 141-151.

Sundbo, J. 1998. The organisation of innovation in services. Roskilde University Press.

Tether, B. 2005. Do Services Innovate (Differently)? Insights from the European Innobarometer Survey. Industry and Innovation, 12: 153-184.

Toivonen, M. 2010. Different types of innovation processes in services and their organisational implications. In: F., Gallouj \& F., Djellal, F. (eds), The Handbook of Innovation and Services: a multidisciplinary perspective, 221-249. Edward Elgar Publishers.

Wettenhall, R. 2003. The Rhetoric and Reality of Public-Private Partnerships. Public Organization Review, 3(1): 77-107.

Widdus, R., Holm, K., Chacko, S. \& Currat, L. 2001. Towards better defining 'public-private partnerships' for health. Geneva: Initiative on Public-Private Partnerships for Health, Global Forum for Health Research.

Windrum, P. \& Garcia-Goni, M. 2008. A neo-Schumpeterian model of health services innovation. Research Policy, 37: 649-672. 


\section{Figure 1}

An exogenous view of innovation: the black box of hospital innovation and of IPPPs

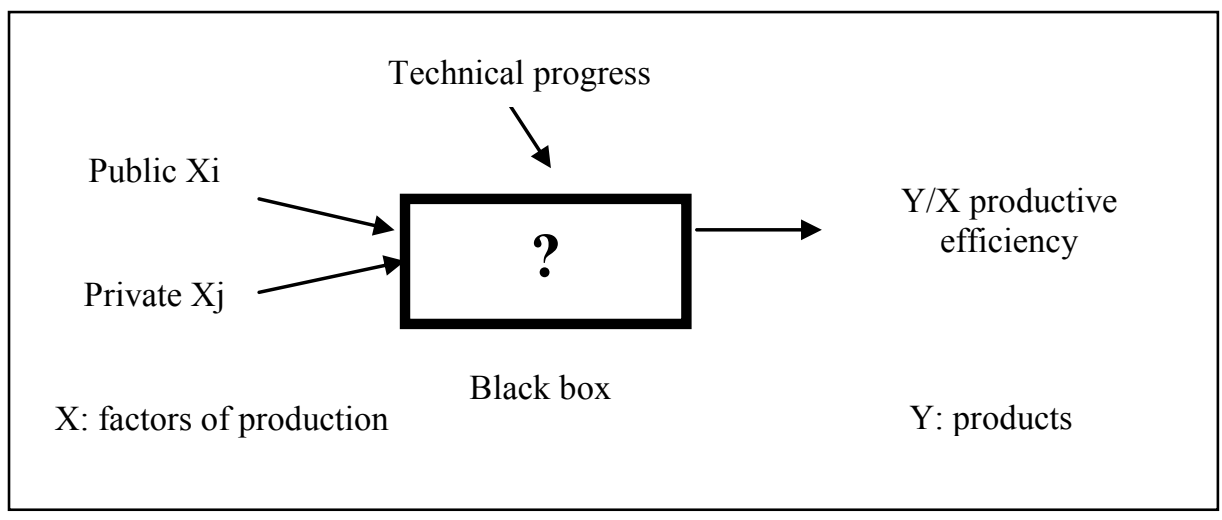




\section{Figure 2}

The product as the conjunction of vectors of characteristics and competences (after Gallouj and Weinstein, 1997)

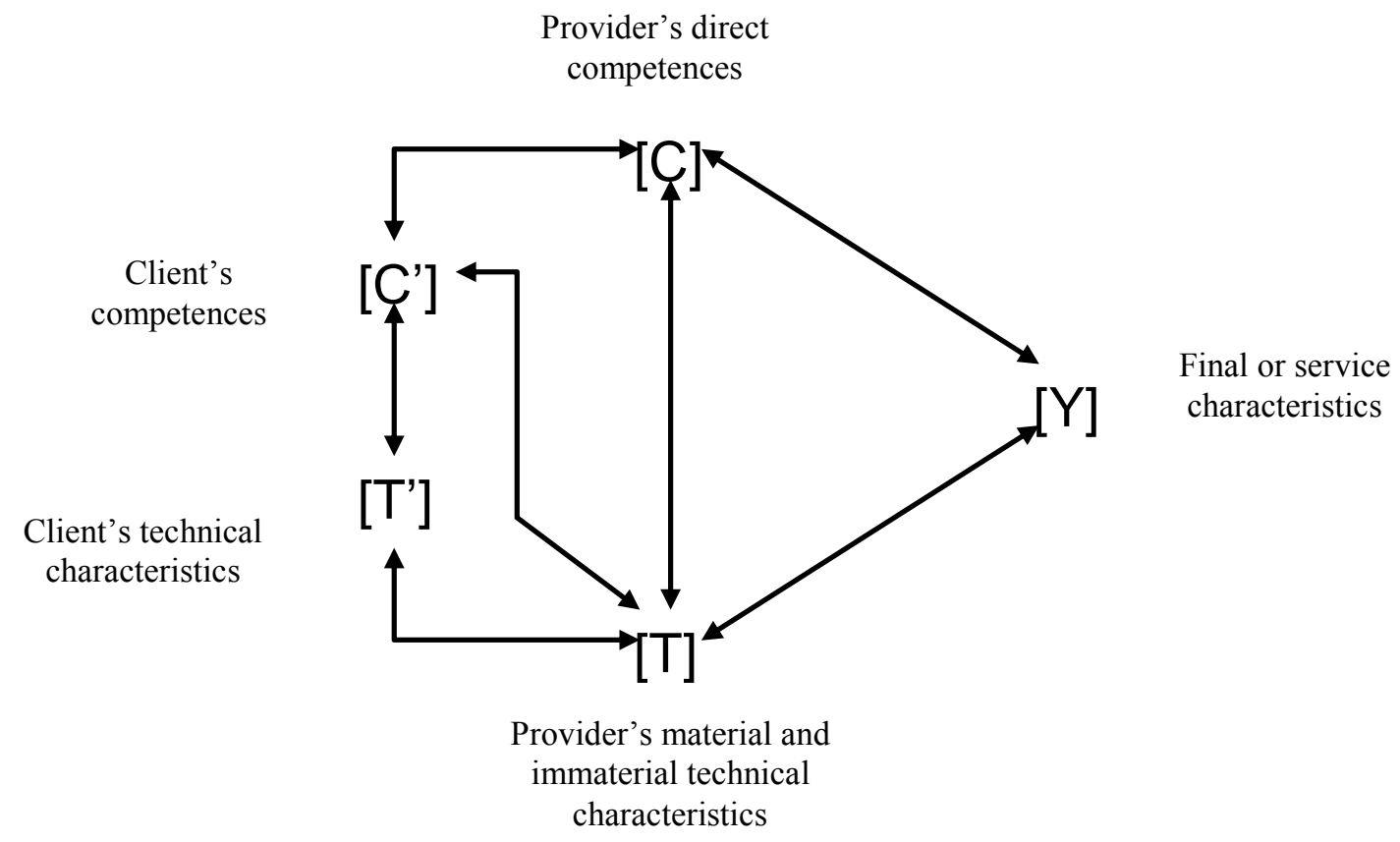




\section{Figure 3}

\section{Innovation-oriented PPPs by degree of complexity}

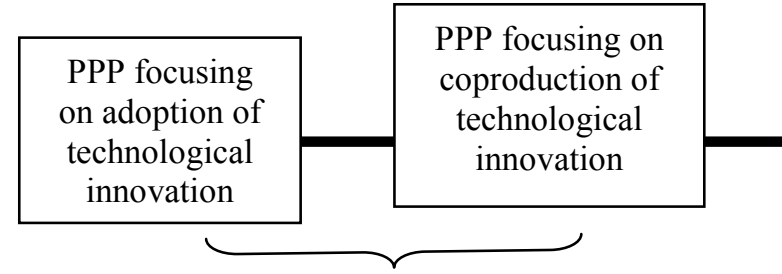

Assimilation

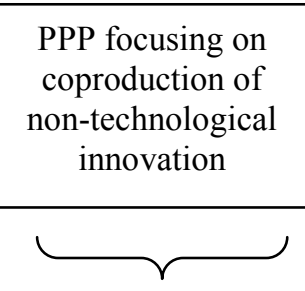

Demarcation
PPP focusing on complex

architectural innovation

V

Integration 
Table 1

A framework for analysing the hospital product (after Djellal et al., 2004)

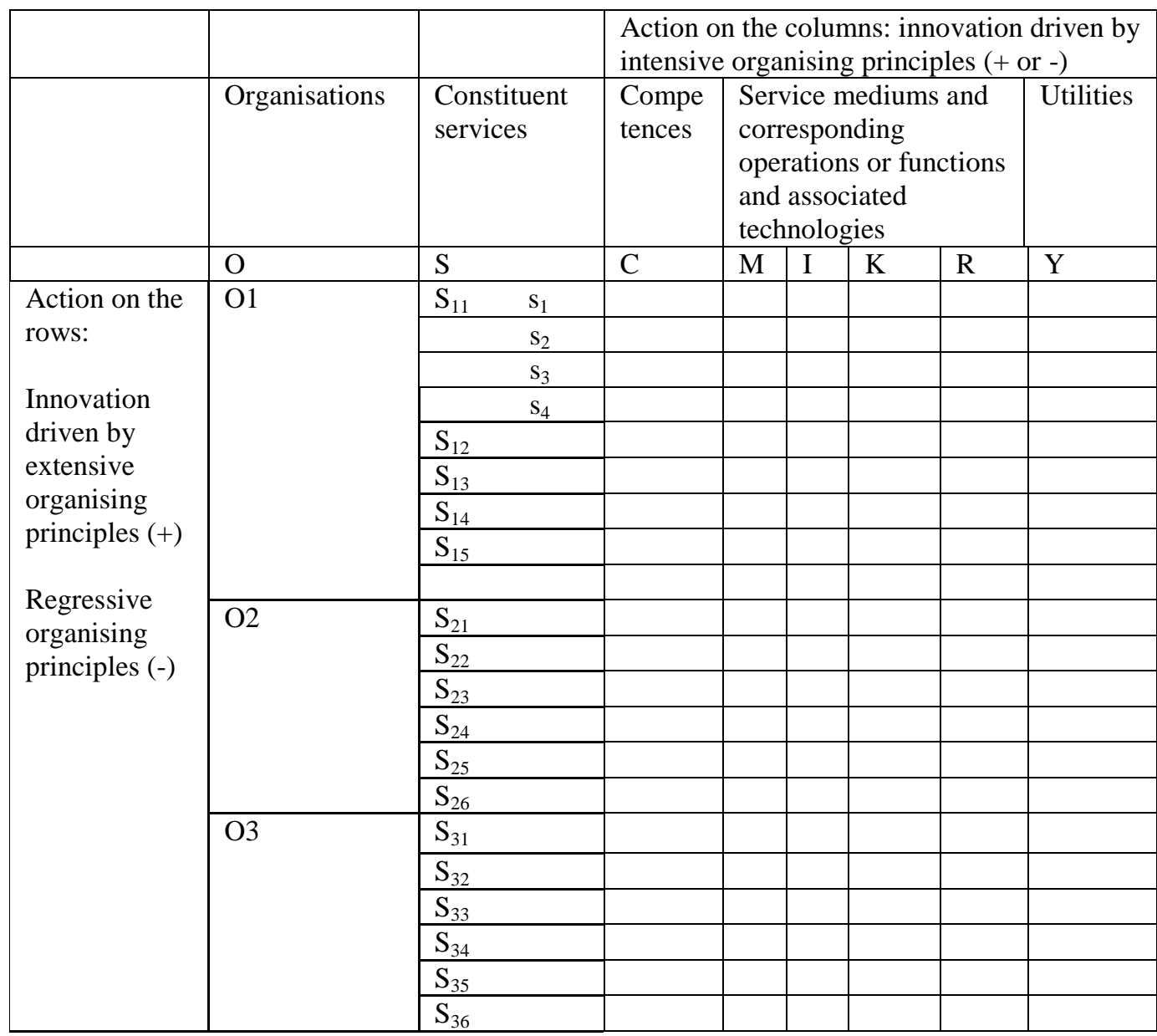


Table 2

The CHV and the Clinique Teissier before the partnership (1999): identifying the duplication (non-exhaustive list)

\begin{tabular}{|l|l|l|l|l|}
\hline $\begin{array}{l}\text { Organisations } \\
\text { (O) }\end{array}$ & Constituent services (Si) & \multicolumn{3}{|l|}{ Technologies } \\
(Ti)
\end{tabular}

\begin{tabular}{|l|l|l|l|l|}
\hline $\begin{array}{l}\text { Organisations } \\
\text { (O) }\end{array}$ & Constituent services (Si) & \multicolumn{3}{|l|}{$\begin{array}{l}\text { Technologies } \\
\text { (Ti) }\end{array}$} \\
\hline $\begin{array}{l}\text { O2. Clinique } \\
\text { Teissier }\end{array}$ & $\begin{array}{l}\text { S1. Thoracic, digestive } \\
\text { and abdominal surgery }\end{array}$ & & TF & \\
\hline & $\begin{array}{l}\text { S8. Accident and } \\
\text { emergency }\end{array}$ & & & \\
\hline & S9. Respiratory medicine & & & \\
\hline & S10. Hotel services & & & \\
\hline & S11. Catering & & & \\
\hline & $\begin{array}{l}\text { S12. Administration - } \\
\text { Management }\end{array}$ & & \\
\hline
\end{tabular}

TF - Technical facilities Duplicated departments

(Source: after Djellal et al. 2004, applied to case under investigation) 
Table 3

The distribution of constituent services between the CHV and the Clinique Teissier before and after the PPP

SITUATION BEFORE THE PPP (non-exhaustive list)

\begin{tabular}{|c|c|c|c|}
\hline \multirow{2}{*}{$\begin{array}{l}\text { Organisa } \\
\text { tions } \\
\text { (O) } \\
\text { O1. CHV }\end{array}$} & \multirow{2}{*}{$\begin{array}{l}\text { Constituent services (Si) } \\
\text { S1. Surgery }\end{array}$} & \multicolumn{2}{|c|}{ Technologies (Ti) } \\
\hline & & $\begin{array}{l}\text { T1 } \\
\text { TF }\end{array}$ & $\begin{array}{l}\text { T2 } \\
\text { IS }\end{array}$ \\
\hline & $\begin{array}{l}\text { S2. Child and adult } \\
\text { psychiatry }\end{array}$ & & \\
\hline & S4. Care of the elderly & & \\
\hline & $\begin{array}{l}\text { S5. Aftercare and } \\
\text { rehabilitation }\end{array}$ & & \\
\hline & S6. Cardiology & & \\
\hline & $\begin{array}{l}\text { S7. Traumatology (accident } \\
\text { surgery) }\end{array}$ & & \\
\hline & $\begin{array}{l}\text { S8. Accident and } \\
\text { emergency }\end{array}$ & & \\
\hline & S9. Respiratory medicine & & \\
\hline & S10. Hotel services & & \\
\hline & S11. Catering & & \\
\hline & $\begin{array}{l}\text { S12. Administration- } \\
\text { Management }\end{array}$ & & \\
\hline & S13. Laundry & & \\
\hline & S14. Pharmacy & & \\
\hline & S15. Laboratories & & \\
\hline
\end{tabular}

\begin{tabular}{|c|c|c|c|}
\hline & Constituent services $(\mathbf{S i})$ & \multicolumn{2}{|c|}{ Technologies (Ti) } \\
\hline $\begin{array}{l}\text { O2. } \\
\text { Teissier }\end{array}$ & $\begin{array}{l}\text { S1. Thoracic, digestive and } \\
\text { abdominal surgery }\end{array}$ & $\begin{array}{l}\text { T1 } \\
\text { TF }\end{array}$ & $\begin{array}{l}\text { T2 } \\
\text { IS }\end{array}$ \\
\hline & $\begin{array}{l}\text { S8. Accident and } \\
\text { emergency }\end{array}$ & & \\
\hline & S9. Respiratory medicine & & \\
\hline & S10. Hotel services & & \\
\hline & S11. Catering & & \\
\hline & $\begin{array}{l}\text { S12. Administration- } \\
\text { Management }\end{array}$ & & \\
\hline & S13. Laundry & & \\
\hline & S14. Pharmacy & & \\
\hline & S15. Laboratories & & \\
\hline
\end{tabular}

$\mathrm{TF}=$ technical facilities. IS = information system. Shaded: the duplications

SITUATION AFTER THE PPP (non-exhaustive list)

\begin{tabular}{|c|c|c|c|c|c|}
\hline Organisation & Organisations & Constituent services (Si) & \multicolumn{3}{|c|}{ Technologies (Ti) } \\
\hline \multirow{18}{*}{$\begin{array}{l}\text { Jean-Bernard } \\
\text { Hospital }\end{array}$} & & & $\begin{array}{l}\text { T1 } \\
\text { TF }\end{array}$ & $\begin{array}{l}\mathrm{T} 2 \\
\mathrm{TF}\end{array}$ & $\begin{array}{l}\text { T3 } \\
\text { IS }\end{array}$ \\
\hline & O1. CHV & S1. Surgery & $\mathrm{X}$ & & \\
\hline & & S2. Child and adult psychiatry & $\mathrm{X}$ & & \\
\hline & & S4. Care of the elderly & $\mathrm{X}$ & & \\
\hline & & S5. Aftercare and rehabilitation & $\mathrm{X}$ & & \\
\hline & & S6. Cardiology & $\mathrm{X}$ & & \\
\hline & & S7. Traumatology & $\mathrm{X}$ & & \\
\hline & & S16. Neurology & $\mathrm{X}$ & & \\
\hline & & & & & \\
\hline & (shared service) & S8. Accident and emergency & $\mathrm{X}$ & & \\
\hline & (shared service) & S10 Hotel services & & & \\
\hline & (shared service) & S11. Catering & & & \\
\hline & (shared service) & S13. Laundry & & & \\
\hline & (shared service) & S14. Pharmacy & & & \\
\hline & (shared service) & S15. Laboratories & & & \\
\hline & O2. Teissier & S9. Respiratory medicine & & $\mathrm{X}$ & \\
\hline & & $\begin{array}{l}\text { S17. Aftercare and rehabilitation } \\
\text { (respiratory speciality) }\end{array}$ & & $\mathrm{X}$ & \\
\hline & & S18. Hospital at home services & & $\mathrm{X}$ & \\
\hline
\end{tabular}

(Source: after Djellal and Gallouj (2005) and adapted to the case under investigation) 